\title{
METODE DE MONITORIZARE ŞI COMBATERE A DĂUNĂTORULUI MOLIA MINIERĂ A TOMATELOR ( Tuta absoluta) ÎN SPAȚIILE PROTEJATE
}

\author{
Savranschii D., Todiraș V., Tretiacova T., Guşan A., Hudeacova $O$. \\ Institutul de Genetică, Fiziologie şi Protecţie a Plantelor, Chişinău, Republica Moldova \\ https://doi.org/10.53040/9789975347204.23
}

\begin{abstract}
Tuta absoluta comes from South America. In Europe it was reported for the first time in Spain in 2006. In Republic of Moldova, according to the literary sources, the tomato moth was reported for the first time in 2013 (in Chişinău). In the absence of some efficient prevention and combating measures of the Tuta absoluta pest it spread more and more, and became a pest of major concern for all the Moldavians farmers which deals with the cultivation of tomato crops in the protected areas. Following the phyto sanitary controls the most cases was found the central region of the country. For the monitoring of the tomato moth pest, in the protected area, was used the water universal trap, the ultraviolet light, the colored adhesive plates and sexual pheromones. As a chemical method of the tomato moth pest combating was used: the insecticide Afirm WG dose of $1.50 \mathrm{~kg} / \mathrm{ha}$.
\end{abstract}

Keywords: Tuta absoluta, Tomatoes, sexual pheromones, monitoring, combating.

\section{Introducere}

Unul din dăunătorii care în ultimii ani a căpătat o răspîndire tot mai vastă dar a devenit și un dăunător de îngrijorare majoră pentru fermierii din Republica Moldova care se ocupă cu cultivarea culturilor de tomate în spațiile protejate este molia minieră a tomatelor (Tuta absoluta). În urma controalelor fitosanitare care sau efectuat, cele mai multe cazuri au fost depistate în localitățile din centrul și sudul țării la culturile de tomate. Molia minieră a tomatelor este originară din America de Sud. În Europa a fost semnalată pentru prima dată în Spania în anul 2006 iar în Moldova din surse literare a fost semnalată în anul 2011. Moliile adulte sunt de culoare gri-maroniu, au o lungime de 5-7 mm, anvergura aripilor fiind cuprinsă între $8-10 \mathrm{~mm}$. Masculii au o culoare mai închisă decât femelele. Ouăle sunt relativ mici $(0,35 \mathrm{~mm}$ lungime), cilindrice, de culoare crem. Molia minieră a tomatelor poate 
produce pagube tuturor organelor supraterane ale plantelor de tomate în toate fazele de vegetaţie. Larvele preferă frunzele şi tulpinile, dar pot ataca atât mugurii florali cât şi fructele. Caracteristic atacului este faptul că larvele produc galerii în organele dăunate. Din acest motiv minele provocate de larve apar, la început, sub forma unor pete mici de culoare albiciosă. Prezența adulților este mai greu de observat, avînd in vedere zborul nocturn al acestor insecte. Ziua, adulții stau ascunși printre frunzele plantelor gazdă și nu dăunează în mod direct culturii. Larvele sunt cele care determină pagubele în culturi, avînd în vedere că după eclozare se hrănesc continuu timp de 12-15 zile, de-a lungul celor 4 stadii larvare. Primele atacuri se pot observa sub forma galeriilor din frunze sau asupra vîrfului de creștere, florilor și tinerelor fructe, prin prezența excrementelor negre ale larvelor.

Scopul cercetării este evaluarea metodelor de monitorizare și combatere a dăunătorului molia minieră a tomatelor din spațiile protejate la cultura tomate.

\section{Material și metode}

Testarea s-a efectuat în zona de centru a Moldovei, în spaţiul protejat al Institutului de Genetică, Fiziologie şi Protecţie a Plantelor, pe lotul cu soiul de tomate „Tolstoi”.

Obiectul de testare a fost produsul chimic - insecticidul Afirm WG, substanţa activă emamectin benzoat, $9.5 \mathrm{~g} / \mathrm{kg}$. La începutul fiecărei experienţei a fost tras planul experienţelor, ceea ce permite orientarea exactă in spaţiul protejat şi identificarea fiecărei variante. Combaterea dăunătorului la tomate în seră s-a bazat pe cunoaşterea exactă a speciei. Datele necesare acestei acţiuni s-au obţinut prin controlul fitosanitar, care s-a executat sistematic in cursul perioadei de vegetaţie, stabilindu-se densitatea populaţiei şi intensitatea atacului. Densitatea numerică se exprimă prin numărul mediu de indivizi al unui dăunător pe unitatea de control.

Monitorizarea moliei minieră a tomatelor sa făcut cu ajutorul capcanei universale cu apă, lumină ultravioletă, plăci adezive colorate și feromon sexual. Dispozitivul dat este conceput pentru depistarea și monitorizarea insectelor dăunătoare la culturile legumicole în spațiile protejate, dar și pentru semnalizarea termenelor de tratare cu insecticide împotriva dăunătorilor. Molia minieră a tomatelor este o insectă cu activitate nocturnă, diminuarea numărului de insecte se datorează faptului, că dispozitivul asigură amplificarea efectului de atracție a moliei miniere prin utilizarea feromonului sexual și prin utilizarea unei surse de lumină ultravioletă cu lungime de undă în intervalul 310-365 nm, care contribuie la sporirea eficacităţii de exterminare ulterioară cu ajutorul foliilor adezive de culoare galbenă și albastră dar și cu a colectorului de insecte în formă de vas cu apă. Structura feromonului sexual a molie minieră este cunoscută ca amestecul din acetații (E,Z,Z)-3,8,11 tetradecatrienilacetat - component principal şi (E,Z)- 3,8 - tetradecatrienilacetat componentul minor. Pentru un rezultat mai efectiv, dispozitivul dat se montează la un nivel cu vîrful de creștere a plantelor de tomate.

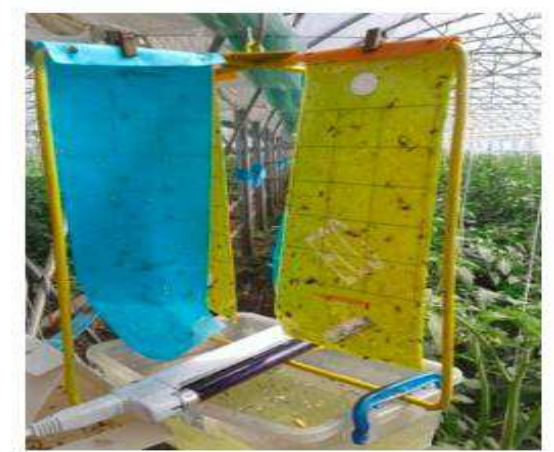

Foto. 1. Molia minieră a tomatelor capturată în capcana universală. 


\section{Rezultate și discuții}

Ca metodă de combatere a moliei miniere a tomatelor sa utilizat insecticidul Afirm, WG. Insecticidul a fost utilizat în perioada de vegetaţie la tomate cu ajutorul stropitoarei manuale. Toate variantele au fost tratate în aceeaşi zi. Evidențele au fost efectuate înăinte de tratament, apoi la a 3-a, 5-a, 7-a și a 10-a zi după tratament. Testarea s-a efectuat în 4 variante. Fiecare variantă a inclus câte patru repetări, fiecare repetare cu câte $25 \mathrm{~m}^{2}$ de teren.

La evidenţa efectuată înainte de stropire pe plantele model au fost înregistraţi 7-11mine /10 frunze, numărul de plante atacate a oscilat de la 3 până la 5 pe o variantă. Evaluând datele obţinute după primul tratament s-a observat micşorarea numărului de mine în raport cu martorul netratat. Eficacitatea biologică a preparatul Afirm WG în combaterea moliei miniere a tomatelor a fost înregistrată peste 72 ore după tratament. Astfel, s-a constatat moartea adulţilor şi larvelor în mine pe frunzele plantelor de tomate. Eficacitatea biologică la variantele preparatului Afirm WG la a 3-a zi a fost egală cu 79.76\% la varianta Afirm WG în doza $1,4 \mathrm{~kg} / \mathrm{ha}$ şi la varianta Afirm WG în doza $1,5 \mathrm{~kg} / \mathrm{ha}-88,17 \%$. Cea mai înaltă eficacitatea biologică a preparatului testat Afirm WG în combaterea moliei miniere a tomatelor Tuta absoluta din seră a fost la a 5-a zi după tratare şi a constituit 85.23-94.87\%. Eficacitatea preparatului la a 7-a zi după tratament a fost 84,37 şi 94,41\% ( tabelul 2).

Tabelul 1. Schema experienței

\begin{tabular}{|c|c|c|c|}
\hline № & $\begin{array}{c}\text { Varianta } \\
\text { testării }\end{array}$ & Cultura & $\begin{array}{c}\text { Metoda } \\
\text { Tratării }\end{array}$ \\
\hline $\mathbf{1}$ & MARTOR & Tomate, s. “Tolstoi” & Netratat \\
\hline $\mathbf{2}$ & $\begin{array}{c}\text { Afirm, WG } \\
-1,4 \mathrm{~kg} / \mathrm{ha}\end{array}$ & Tomate, s. “Tolstoi” & $\begin{array}{c}\text { Stropirea în perioada de } \\
\text { vegetaţie }\end{array}$ \\
\hline $\mathbf{3}$ & $\begin{array}{c}\text { Afirm, WG } \\
-1,5 \mathrm{~kg} / \mathrm{ha}\end{array}$ & Tomate, s. “Tolstoi” & $\begin{array}{c}\text { Stropirea în perioada de } \\
\text { vegetaţie }\end{array}$ \\
\hline
\end{tabular}

Tabelul 2. Eficacitatea biologică a insecticidului testat Afirm, WG în combaterea moliei miniere a tomatelor.

\begin{tabular}{|c|c|c|c|c|c|c|c|c|c|c|c|c|}
\hline \multirow{3}{*}{ Variantă } & \multirow{3}{*}{$\begin{array}{c}\text { Norma } \\
\text { de } \\
\text { consum, } \\
\text { l/ha }\end{array}$} & \multirow{3}{*}{ '要 } & \multicolumn{5}{|c|}{$\begin{array}{c}\text { Densitatea numerică medie a minelor la } 10 \\
\text { frunze }\end{array}$} & \multirow{2}{*}{\multicolumn{4}{|c|}{$\begin{array}{l}\text { Densitatea numerică a dăunătorului, în } \\
\% \text { comparativ cu martorul netratat în } \\
\text { zilele de evidență }\end{array}$}} & \multirow{3}{*}{$\begin{array}{l}\text { Eficacitatea } \\
\text { biologică } \\
\text { medie, \% }\end{array}$} \\
\hline & & & \multirow{2}{*}{$\begin{array}{l}\text { până la } \\
\text { tratare }\end{array}$} & \multicolumn{4}{|c|}{ În zilele de cvidență } & & & & & \\
\hline & & & & 3 & 5 & 7 & 10 & 3 & 5 & 7 & 10 & \\
\hline 1 & 2 & 4 & 5 & 6 & 7 & 8 & & 10 & $I I$ & 12 & 13 & 14 \\
\hline \multirow{5}{*}{$\begin{array}{l}\text { Afirm, } \\
\text { WG }\end{array}$} & \multirow{5}{*}{$\begin{array}{c}1,4 \\
\mathrm{~kg} / \mathrm{ha}\end{array}$} & 1 & 10.00 & 2.50 & 2.20 & 2.40 & 3.50 & 77.09 & 82.72 & 83.50 & 78.62 & 80.48 \\
\hline & & 2 & 8.00 & 2.00 & 1.70 & 2.10 & 3.20 & 77.28 & 83.66 & 82.50 & 76.48 & 79.98 \\
\hline & & 3 & 9.00 & 2.00 & 1.70 & 2.20 & 3.50 & 81.82 & 86.93 & 85.34 & 79.42 & 83.38 \\
\hline & & 4 & 7.00 & 1.50 & 1.30 & 1.70 & 2.80 & 82.86 & 87.62 & 86.13 & 80.00 & 84.15 \\
\hline & & Med. & 8.50 & 2.00 & 1.70 & 2.10 & 3.25 & 79.76 & 85.23 & 84.37 & 78.63 & 82.00 \\
\hline \multirow{5}{*}{$\begin{array}{l}\text { Afirm, } \\
\text { WG }\end{array}$} & \multirow{5}{*}{$\begin{array}{c}1,5 \\
\mathrm{~kg} / \mathrm{ha}\end{array}$} & 1 & 11.00 & 2.00 & 1.00 & 1.10 & 2.00 & 83.34 & 92.85 & 93.12 & 88.89 & 89.55 \\
\hline & & 2 & 10.00 & 1.50 & 0.50 & 0.8 & 2.00 & 86.37 & 96.42 & 94.66 & 88.24 & 91.42 \\
\hline & & 3 & 11.00 & 1.00 & 0.50 & 0.60 & 1.50 & 92.56 & 96.85 & 96.72 & 92.78 & 94.73 \\
\hline & & 4 & 10.00 & 1.20 & 1.00 & 1.20 & 2.50 & 90.40 & 93.34 & 93.14 & 87.50 & 91.10 \\
\hline & & Med. & 10.50 & 1.43 & 0.75 & 0.93 & 2.00 & 88.17 & 94.87 & 94.41 & 89.35 & 91.70 \\
\hline \multirow{5}{*}{ Martor } & & 1 & 11.00 & 12.00 & 14.00 & 16.00 & 18.00 & 0 & 0 & 0 & 0 & 0 \\
\hline & & 2 & 10.00 & 11.00 & 13.00 & 15.00 & 17.00 & 0 & 0 & 0 & 0 & 0 \\
\hline & & 3 & 9.00 & 11.00 & 13.00 & 15.00 & 17.00 & 0 & 0 & 0 & 0 & 0 \\
\hline & & 4 & 8.00 & 10.00 & 12.00 & 14.00 & 16.00 & $\pi$ & 0 & 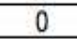 & 0 & 0 \\
\hline & & Med. & 9.50 & 11.00 & 13.00 & 15.00 & 17.00 & $v$ & 0 & 0 & 0 & 0 \\
\hline & 1.51 & 0.7 & 0.98 & 1.0 & 1.27 & 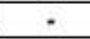 & - & - & & 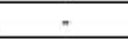 \\
\hline
\end{tabular}




\section{Concluzii}

1. Capcana universală reprezintă o metodă ecologică pentru monitorizare și capturarea musculiței miniere a tomatelor din spațiile protejate, și cu perspectivă în sistemul de măsuri în protecția plantelor.

2. Insecticidul Afirm, WG în doza de $1,50 \mathrm{~kg} / \mathrm{ha}$, are o eficacitate biologică mai ridicată în comparație cu doza de $1,40 \mathrm{~kg} / \mathrm{ha}$ în combaterea moliei miniere a tomatelor (Tuta absoluta).

\section{Bibliografie}

1. Baicu, T.;Săvescu, A. Combaterea integrată în protecția plantelor. București: Ed. Ceres, 1978-327p.

2. Baicu, T.;Săvescu, A. Sisteme de combatere integrată a bolilor și dăunătorilor pe culturi. București:Ed.Ceres, 1986-264p.

3. Costache, M.;Roman, T. Gid pentru recunoașterea și combaterea agenților patogeni și a dăunătorilor la lugume. București: Agris, 1998-150p.

4. Danilov, N. Registrul de Stat al produselor de uz fitosanitar și al fertilizanților, permiși pentru utilizarea în Republica Moldova. Chișinău Tip. Centr., 2003, 380p.

5. Доспехов Б.А. Методика полевого опыта. Москва: Агропромиздат, 1985. 351 с.

6. Mustață, Gh. Biologia și ecologia insectelor parazite în insecte dăunătopare legumelor din Moldova. Iași, Univ., Al. I. Cuza, 1991. 350p.

7. Roșca, I.; Vasiliescu, B. Protecția integrată a culturilor agricole împotriva bolilor și dăunătorilor. Curs. București: UASM; 1996-156p.

8. Îndrumări metodice pentru testarea produselor chimice si biologice de protecţie a plantelor de dăunători, boli şi buruieni în Republica Moldova. Centrul de Stat pentru Atestarea produselor Chimice şi Biologice de Protecţie şi Stimulare a Creşterii Plantelor. Chişinău: F.E.P. Tipografia Centrală, 2002. 286 p. 